\title{
URGENSITAS PERLINDUNGAN SAKSI DAN KORBAN \\ DALAM MENGUNGKAP KASUS KEKERASAN \\ DALAM RUMAH TANGGA
}

\author{
Syamsul Fatoni* \\ Bagian Hukum Pidana Fakultas Hukum Universitas Trunojoyo, Bangkalan \\ Jalan Raya Telang PO Box 2 Kamal, Bangkalan, Jawa Timur 69162
}

\begin{abstract}
Legal maintenance concerning violence case within household as stated by Act Number 23, 2004 about Violence erasing within household, still poor. That case related with problem within Substance of Act Number 13, 2006 about both Witness and Victim Protection, which less accommodate legal need for both witness and victim (including reporting person) therefore both witness and victim were less braveness to reveal criminal case occurred. Besides that, include problem within structure (especially presence protection institution for both witness and victim and legal actor) and society legal culture who tend to solve by kinship way.
\end{abstract}

Keywords: witness, victim, institution, structure, culture.

\section{Intisari}

Struktur (aparat penegak hukum termasuk LPSK), substansi UU dan budaya hukum masyarakat yang cenderung menyelesaikan kasus KDRT secara kekeluargaan, berpengaruh dalam mengungkap terjadinya tindak pidana. Eksistensi UU Nomor 13 Tahun 2006 tentang Perlindungan Saksi dan Korban serta Peraturan Pemerintah Republik Indonesia Nomor 44 Tahun 2008 tentang Pemberian Kompensasi, Restitusi, dan Bantuan Kepada Saksi dan Korban telah menunjukkan kemajuan negara dalam memberikan perlindungan pada saksi dan korban. Politik hukum di masa mendatang berupa regulasi peraturan harus mengakomodir kebutuhan hukum untuk memenuhi rasa keadilan bagi masyarakat, khususnya saksi dan korban (termasuk pelapor), dimana peran LPSK harus proaktif, professional serta proporsional.

Kata Kunci: saksi, korban, institusi, struktur, budaya.

\section{Pokok Muatan}

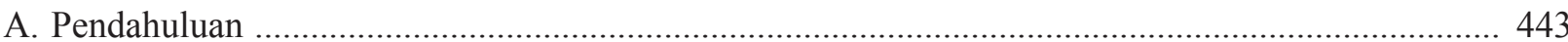

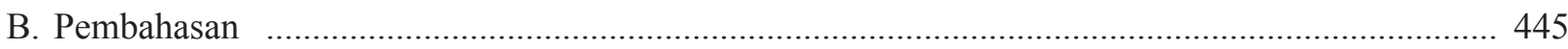

1. Politik Hukum Berkaitan dengan Perlindungan Saksi, Korban dan Pelapor/Pengadu ............... 445

2. Sistem Penegakan Hukum Pidana terhadap Kekerasan dalam Rumah Tangga (KDRT) ............ 447

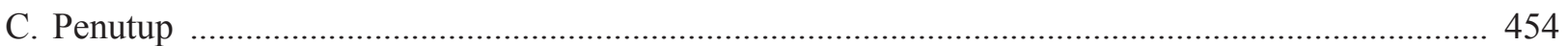




\section{A. Pendahuluan}

Data yang dihimpun oleh Komnas Perempuan, tahun 2012 terdapat 216.156 kasus kekerasan terhadap perempuan yang dilaporkan dan ditangani. Berdasarkan data tersebut, 203.507 kasus bersumber pada data kasus/perkara yang ditangani oleh 329 Pengadilan Agama (data BADILAG), 87 PN dan PM (data BADILUM) dan 2 UPPA (data UPPA) serta 12.649 kasus yang ditangani oleh 225 lembaga mitra pengadaan pelayanan yang tersebar di 30 provinsi (mengalami kenaikan hampir $81 \%$ atau dua kali lipat dari data tahun sebelumnya). Data Pengadilan Agama menunjukkan, kekerasan yang terjadi terhadap istri di ranah personal mencatat kasus paling tinggi, sejumlah 203.507 kasus. Sementara dari 12.649 kasus yang masuk dari lembaga mitra pengadaan layanan, kekerasan yang terjadi di ranah personal tercatat $66 \%$ atau 8.315 kasus $(42 \%$ atau 4.305 kasus berupa kekerasan terhadap istri).

Data yang berhasil dihimpun hanyalah data yang terlaporkan sebab masih banyak korban kekerasan dalam rumah tangga yang tidak melaporkan kasusnya. Hal itu dipengaruhi oleh berbagai hal, antara lain: malu sebab akan membuka aib keluarga, tidak tahu ke mana harus melaporkan, dampak kekerasan jika dilaporkan (psikologis dan fisik seperti pembunuhan dan penganiayaan), pelakunya dalam lingkup rumah sehingga pelaku dan korban merupakan anggota keluarga sehingga sering dianggap bukan sebagai bentuk kekerasan.

KDRT dapat dilakukan oleh istri atau suami, meskipun data yang ada menunjukkan bahwa kecenderungan pelakunya adalah suami. Penyebabnya antara lain: laki-laki dan perempuan tidak dalam posisi yang setara, masyarakat menganggap laki-laki harus kuat, berani serta tanpa ampun, KDRT dianggap bukan sebagai permasalahan sosial, tetapi persoalan pribadi terhadap relasi suami istri, pemahaman keliru terhadap ajaran agama, sehingga timbul anggapan bahwa laki-laki boleh menguasai perempuan.

KDRT awalnya bukan masuk domain Negara tetapi lebih pada domain privat sehingga kehadiran Undang-Undang Nomor 23 Tahun 2004 tentang Penghapusan Kekerasan dalam Rumah Tangga (selanjutnya disingkat PKDRT), memberikan landasan yuridis untuk memproses pelakunya. ${ }^{1}$ Apalagi dalam perkembangannya terkait dengan penegakan Hak Asasi Manusia (HAM), sehingga kehidupan berumah tangga sudah public concern (perhatian publik). Konsekuensinya, persoalan dalam rumah tangga khususnya yang terkait dengan kekerasan, menjadi dikriminalisasikan.

Konsepsi kekerasan sebagai kejahatan dalam konteks kehidupan berumah tangga, sebagaimana yang dikonsepsikan dalam Pasal 1 angka 1 UndangUndang Nomor 23 Tahun 2004 tentang Penghapusan Kekerasan Dalam Rumah adalah sebagai berikut:

Kekerasan dalam Rumah Tangga adalah setiap perbuatan terhadap seseorang terutama perempuan, yang berakibat timbulnya kesengsaraan atau penderitaan secara fisik, seksual, psikologis, dan/atau penelantaran rumah tangga termasuk ancaman untuk melakukan perbuatan, pemaksaan, atau perampasan kemerdekaan secara melawan hukum dalam lingkup rumah tangga. ${ }^{2}$

Sedangkan dalam Undang-Undang Nomor 23 Tahun 2004 tentang Penghapusan Kekerasan dalam Rumah Tangga, membagi jenis kekerasan:

1. Kekerasan fisik adalah perbuatan yang mengakibatkan rasa sakit, jatuh sakit, atau luka berat. ${ }^{3}$

\footnotetext{
Hal tersebut terlihat dalam konsiderans huruf (b) dan (c) Undang-Undang Nomor 23 Tahun 2004 tentang Penghapusan Kekerasan dalam Rumah Tangga: (b) Bahwa segala bentuk kekerasan, terutama kekerasan dalam rumah tangga, merupakan pelanggaran hak asasi manusia dan kejahatan terhadap martabat kemanusiaan serta bentuk diskriminasi yang harus dihapus, (c) Bahwa korban kekerasan dalam rumah tangga, yang kebanyakan adalah perempuan, harus mendapat perlindungan dari negara dan/atau masyarakat agar terhindar dan terbebas dari kekerasan atau ancaman kekerasan, penyiksaan, atau perlakuan yang merendahkan derajat dan martabat kemanusiaan (Undang-Undang Nomor 23 Tahun 2004 tentang Penghapusan Kekerasan dalam Rumah Tangga (Lembaran Negara Republik Indonesia Tahun 2004 Nomor 95, Tambahan Lembaran Negara Republik Indonesia Tahun 2004 Nomor 4419)).

Pasal 1 angka 1 Undang-Undang Nomor 23 Tahun 2004 tentang Penghapusan Kekerasan dalam Rumah Tangga (Lembaran Negara Republik Indonesia Tahun 2004 Nomor 95, Tambahan Lembaran Negara Republik Indonesia Tahun 2004 Nomor 4419).

Pasal 6 Undang-Undang Nomor 23 Tahun 2004 tentang Penghapusan Kekerasan dalam Rumah Tangga (Lembaran Negara Republik Indonesia Tahun 2004 Nomor 95, Tambahan Lembaran Negara Republik Indonesia Tahun 2004 Nomor 4419).
} 
2. Kekerasan psikis adalah perbuatan yang mengakibatkan ketakutan, hilangnya rasa percaya diri, hilangnya kemampuan untuk bertindak, rasa tidak berdaya, dan/atau penderitaan psikis berat pada seseorang. ${ }^{4}$

3. Kekerasan seksual meliputi pemaksaan hubungan seksual yang dilakukan terhadap orang yang menetap dalam lingkup rumah tangga tersebut dan pemaksaan hubungan seksual terhadap salah seorang dalam lingkup rumah tangganya dengan orang lain untuk tujuan komersial dan atau tujuan tertentu. $^{5}$

4. Penelantaran rumah tangga adalah menelantarkan orang dalam lingkup rumah tangganya, padahal menurut hukum yang berlaku baginya atau karena persetujuan atau perjanjian ia wajib memberikan kehidupan, perawatan, atau pemeliharaan kepada orang tersebut. Penelantaran juga berlaku bagi setiap orang yang mengakibatkan ketergantungan ekonomi dengan cara membatasi dan/atau melarang untuk bekerja yang layak di dalam atau di luar rumah sehingga korban berada di bawah kendali orang tersebut. ${ }^{6}$

Beijing Rule memberikan makna yang luas dalam kekerasan sebagai refleksi dari pengakuan atas realita bahwa bentuk dan akibat dari kekerasan sangat beragam. Pasal 1 Deklarasi Penghapusan Kekerasan terhadap Perempuan memberikan definisi kekerasan terhadap perempuan:

Kekerasan terhadap Perempuan adalah setiap tindakan berdasarkan perbedaan jenis kelamin (gender-based violence) yang berakibat atau mungkin berakibat kesengsaraan atau penderitaan perempuan secara fisik, seksual atau psikologis, termasuk ancaman tindakan tertentu, pemaksaan atau perampasan kemerdekaan secara sewenang-wenang, baik yang terjadi di depan umum atau dalam kehidupan pribadi. ${ }^{7}$

Selanjutnya penjelasan Pasal 2 menyatakan:

Kekerasan terhadap perempuan harus dipahami mencakup, tetapi tidak hanya terbatas pada: tindak kekerasan secara fisik, seksual dan psikologis yang terjadi di dalam keluarga dan masyarakat, termasuk pemukulan, penyalahgunaan seksual atas perempuan kanak-kanak, kekerasan yang berhubungan dengan mas kawin, perkosaan dan perkawinan (marital rape), perusakan alat kelamin perempuan, dan praktikpraktik kekejaman tradisional lain terhadap perempuan, kekerasan di luar hubungan suami istri dan kekerasan yang berhubungan dengan eksploitasi perempuan, perkosaan, penyalahgunaan seksual, pelecehan dan ancaman seksual di tempat kerja dalam lembaga-lembaga pendidikan dan sebagainya, perdagangan perempuan dan pelacuran paksa. Serta termasuk kekerasan yang dilakukan dan dibenarkan oleh negara di manapun terjadinya.

Talcott Parsons dan Robert F. Balles berpendapat bahwa keluarga sebagai unit sosial yang memberikan perbedaan peran suami dan istri untuk saling melengkapi dan saling membantu satu sama lain. Karena itu peran keluarga semakin penting dalam masyarakat modern terutama dalam pengasuhan dan pendidikan anak. Keharmonisan hidup hanya dapat diciptakan bila terjadi pembagian peran dan tugas yang serasi antara laki-laki dan perempuan. Aliran ini melahirkan paham struktural fungsional yang menerima perbedaan peran asal dilakukan secara demokratis dan dilandasi oleh

\footnotetext{
Pasal 7 Undang-Undang Nomor 23 Tahun 2004 tentang Penghapusan Kekerasan dalam Rumah Tangga (Lembaran Negara Republik Indonesia Tahun 2004 Nomor 95, Tambahan Lembaran Negara Republik Indonesia Tahun 2004 Nomor 4419).

Pasal 8 Undang-Undang Nomor 23 Tahun 2004 tentang Penghapusan Kekerasan dalam Rumah Tangga (Lembaran Negara Republik Indonesia Tahun 2004 Nomor 95, Tambahan Lembaran Negara Republik Indonesia Tahun 2004 Nomor 4419).

6 Pasal 9 Undang-Undang Nomor 23 Tahun 2004 tentang Penghapusan Kekerasan dalam Rumah Tangga (Lembaran Negara Republik Indonesia Tahun 2004 Nomor 95, Tambahan Lembaran Negara Republik Indonesia Tahun 2004 Nomor 4419).

Achie Sudiarti Luhulima, 2000, Pemahaman Bentuk-Bentuk Tindak Kekerasan terhadap Perempuan dan Alternatif Pemecahannya, Alumni, Bandung, hlm. 150.
} 
kesepakatan antara suami dan istri dalam keluarga atau antara kaum laki-laki dan perempuan dalam hidup masyarakat. ${ }^{8}$

Seringkali praktik penegakan hukum kasuskasus kekerasan dalam rumah tangga, aparat penegak hukum justru terkendala atau mengalami kesulitan, karena tidak dapat menghadirkan saksi dan atau korban disebabkan ancaman baik fisik, psikis dari pihak-pihak tertentu terutama mereka yang merasa terancam dengan keberadaan saksi dan atau korban. Oleh karena itu, tulisan ini akan membahas mengenai: Pertama, bagaimana politik hukum berkaitan dengan perlindungan saksi, korban dan pelapor/pengadu? Kedua, bagaimana sistem penegakan hukum pidana terhadap kekerasan dalam rumah tangga (KDRT)?

\section{B. Pembahasan}

\section{Politik Hukum Berkaitan dengan Perlindungan Saksi, Korban dan Pelapor/ \\ Pengadu}

Sudarto merumuskan, politik hukum adalah usaha untuk mewujudkan peraturan-peraturan yang baik sesuai dengan keadaan dan situasi pada suatu saat serta kebijakan dari suatu Negara melalui Badan-Badan yang berwenang untuk menetapkan peraturan-peraturan yang dikehendaki yang diperkirakan bisa digunakan untuk mengekspresikan apa yang terkandung dalam masyarakat dan mencapai apa yang dicita-citakan. ${ }^{9}$

Pasal 184 Undang-Undang Nomor 8 Tahun 1981 tentang Hukum Acara Pidana (HAP) dimana macam-macam alat bukti yang sah dalam proses peradilan pidana yaitu keterangan saksi, keterangan ahli, surat, petunjuk dan keterangan terdakwa. ${ }^{10}$ Pasal 185 Undang-Undang Nomor 8 Tahun 1981 tentang Hukum Acara Pidana (HAP) terkait dengan keterangan saksi dan atau korban yang mendengar, melihat atau mengalami sendiri terjadinya tindak pidana dan keberadaannya berguna untuk mencari dan menemukan kejelasan tindak pidana yang dilakukan oleh pelaku tindak pidana. ${ }^{11}$ Sehubungan dugaan telah terjadinya Tindak Pidana maka kehadiran saksi dan korban serta pelapor/pengadu memerlukan pengaturan sebab yang selama ini lebih mengedepankan kepentingan tersangka, terdakwa dan terpidana.

Pasal 1 ayat (1) Undang-Undang Nomor 23 Tahun 2004 tentang Penghapusan Kekerasan dalam Rumah Tangga (PKDRT) menyatakan bahwa setiap perbuatan terhadap seseorang terutama perempuan, yang berakibat timbulnya kesengsaraan atau penderitaan secara fisik, seksual, psikologis, dan/atau penelantaran rumah tangga termasuk ancaman untuk melakukan perbuatan, pemaksaan, atau perampasan kemerdekaan secara melawan hukum dalam lingkup rumah tangga. ${ }^{12}$ Sedangkan Pasal 2 ayat (1) Undang-Undang Nomor 23 Tahun 2004 tentang Penghapusan Kekerasan dalam Rumah Tangga (PKDRT) dimana lingkup rumah tangga, suami, isteri, dan anak, orang-orang yang mempunyai hubungan keluarga (karena hubungan darah, perkawinan, persusuan, pengasuhan, dan perwalian, yang menetap dalam rumah tangga; dan atau orang yang bekerja membantu rumah tangga dan menetap dalam rumah tersebut. ${ }^{13}$ Dengan demikian, pelakunya dapat orang dewasa terhadap orang dewasa (suami, isteri, pembantu) atau orang dewasa terhadap anak dan sebaliknya sedangkan korbannya orang dewasa dan anak.

Pasal 26 ayat (1) Undang-Undang tentang Penghapusan Kekerasan dalam Rumah Tangga

\footnotetext{
Talcott Parsons dan Robert F. Bales, 1955, Family, Socialization and Interaction Process, The Free Press, Glencoe, hlm. 23. Sudarto, 1981, Hukum dan Hukum Pidana, Alumni, Bandung, hlm. 159.

Pasal 184 Undang-Undang Nomor 8 Tahun 1981 tentang Hukum Acara Pidana (Lembaran Negara Republik Indonesia Tahun 1982 Nomor 76 , Tambahan Lembaran Negara Republik Indonesia Nomor 3209).

11 Pasal 185 Undang-Undang Nomor 8 Tahun 1981 tentang Hukum Acara Pidana (Lembaran Negara Republik Indonesia Tahun 1982 Nomor 76 , Tambahan Lembaran Negara Republik Indonesia Nomor 3209).

12 Pasal 1 ayat (1) Undang-Undang Nomor 23 Tahun 2004 tentang Penghapusan Kekerasan dalam Rumah Tangga (Lembaran Negara Republik Indonesia Tahun 2004 Nomor 95, Tambahan Lembaran Negara Republik Indonesia Tahun 2004 Nomor 4419).

13 Pasal 2 ayat (1) Undang-Undang Nomor 23 Tahun 2004 tentang Penghapusan Kekerasan dalam Rumah Tangga (Lembaran Negara Republik Indonesia Tahun 2004 Nomor 95, Tambahan Lembaran Negara Republik Indonesia Tahun 2004 Nomor 4419).
} 
menentukan bahwa yang dapat melaporkan jiwanya.

secara langsung adanya KDRT kepada polisi

Pasal 10 Undang-Undang Nomor 23 Tahun adalah korban. ${ }^{14}$ Sebaliknya, Pasal 26 ayat (2) Undang-Undang tentang Penghapusan Kekerasan dalam Rumah Tangga, keluarga atau pihak lain tidak dapat melaporkan secara langsung adanya dugaan KDRT kecuali telah mendapat kuasa dari korban. ${ }^{15}$ Meskipun demikian, pihak keluarga dapat melakukan tindakan lain untuk mencegah berlanjutnya kekerasan terhadap korban. Kewajiban masyarakat untuk turut serta dalam pencegahan KDRT ini diatur dalam Pasal 15 Undang-Undang tentang Penghapusan Kekerasan dalam Rumah Tangga yang berbunyi sebagai berikut:

Setiap orang yang mendengar, melihat, atau mengetahui terjadinya kekerasan dalam rumah tangga wajib melakukan upaya-upaya sesuai dengan batas kemampuannya untuk: (a) mencegah berlangsungnya tindak pidana;

(b) memberikan perlindungan kepada korban;

(c) memberikan pertolongan darurat; dan (d) membantu proses pengajuan permohonan penetapan perlindungan. ${ }^{16}$

UU PKDRT menyebutkan bahwa permohonan (huruf d) dapat disampaikan dalam bentuk lisan atau tulisan. Ditegaskan pula dalam hal permohonan perintah perlindungan diajukan oleh keluarga, teman korban, kepolisian, relawan pendamping, atau pembimbing rohani, maka korban harus memberikan persetujuannya. Namun, Pasal 30 ayat (1), ayat (3), dan ayat (4) UU PKDRT), dalam keadaan tertentu, permohonan dapat diajukan tanpa persetujuan korban. ${ }^{17}$ Yang dimaksud dengan "keadaan tertentu" dalam ketentuan tersebut, misalnya pingsan, koma, dan sangat terancam

\section{4 tentang Penghapusan Kekerasan dalam Rumah Tangga menyebutkan "korban" berhak mendapatkan: ${ }^{18}$}

a. Perlindungan dari pihak keluarga, kepolisian, kejaksaan, pengadilan, advokat, lembaga sosial, atau pihak lainnya baik sementara maupun berdasarkan penetapan perintah perlindungan dari pengadilan.

b. Pelayanan kesehatan sesuai dengan kebutuhan medis.

c. Penanganan secara khusus berkaitan dengan kerahasiaan korban.

d. Pendampingan oleh pekerja sosial dan bantuan hukum pada setiap tingkat proses pemeriksaan sesuai dengan ketentuan peraturan perundangundangan; dan

e. Pelayanan bimbingan rohani.

Pasal 44 ayat (1) Undang-Undang tentang Penghapusan Kekerasan dalam Rumah Tangga mengatur ancaman pidana terhadap kekerasan fisik dalam lingkup rumah tangga ini adalah pidana penjara pidana penjara paling lama 5 (lima) tahun atau denda paling banyak Rp15.000.000,00 (lima belas juta rupiah). ${ }^{19}$ Khusus KDRT yang dilakukan oleh suami terhadap istri yang tidak menimbulkan penyakit atau halangan untuk menjalankan pekerjaan jabatan atau mata pencaharian atau kegiatan sehari-hari, ancaman pidananya adalah pidana penjara paling lama 4 (empat) bulan atau denda paling banyak Rp5.000.000,00 (lima juta rupiah). ${ }^{20}$

Meskipun UU sudah mengatur bentukbentuk perlindungan tersebut, aparat penegak

14 Pasal 26 ayat (1) Undang-Undang Nomor 23 Tahun 2004 tentang Penghapusan Kekerasan dalam Rumah Tangga (Lembaran Negara Republik Indonesia Tahun 2004 Nomor 95, Tambahan Lembaran Negara Republik Indonesia Tahun 2004 Nomor 4419).

15 Pasal 26 ayat (2) Undang-Undang Nomor 23 Tahun 2004 tentang Penghapusan Kekerasan dalam Rumah Tangga (Lembaran Negara Republik Indonesia Tahun 2004 Nomor 95, Tambahan Lembaran Negara Republik Indonesia Tahun 2004 Nomor 4419).

16 Pasal 15 Undang-Undang Nomor 23 Tahun 2004 tentang Penghapusan Kekerasan dalam Rumah Tangga (Lembaran Negara Republik Indonesia Tahun 2004 Nomor 95, Tambahan Lembaran Negara Republik Indonesia Tahun 2004 Nomor 4419).

17 Pasal 30 ayat (1), ayat (3) dan ayat (4) Undang-Undang Nomor 23 Tahun 2004 tentang Penghapusan Kekerasan dalam Rumah Tangga (Lembaran Negara Republik Indonesia Tahun 2004 Nomor 95, Tambahan Lembaran Negara Republik Indonesia Tahun 2004 Nomor 4419 ).

1 Pasal 10 Undang-Undang Nomor 23 Tahun 2004 tentang Penghapusan Kekerasan dalam Rumah Tangga (Lembaran Negara Republik Indonesia Tahun 2004 Nomor 95, Tambahan Lembaran Negara Republik Indonesia Tahun 2004 Nomor 4419).

19 Pasal 44 ayat (1) Undang-Undang Nomor 23 Tahun 2004 tentang Penghapusan Kekerasan dalam Rumah Tangga (Lembaran Negara Republik Indonesia Tahun 2004 Nomor 95, Tambahan Lembaran Negara Republik Indonesia Tahun 2004 Nomor 4419).

20 Pasal 44 ayat (4) Undang-Undang Nomor 23 Tahun 2004 tentang Penghapusan Kekerasan dalam Rumah Tangga (Lembaran Negara Republik Indonesia Tahun 2004 Nomor 95, Tambahan Lembaran Negara Republik Indonesia Tahun 2004 Nomor 4419). 
hukum seringkali terkendala/mengalami kesulitan karena tidak dapat menghadirkan saksi dan atau korban disebabkan ancaman baik fisik, psikis dari pihak-pihak tertentu terutama mereka yang merasa terancam dengan keberadaan saksi dan atau korban.

Dalam Rancangan KUHAP dinyatakan: Setiap pelapor atau pengadu, setiap orang atau korban dan setiap pegawai negeri, berhak memperoleh perlindungan hukum, perlindungan fisik dan perlindungan non fisik. ${ }^{21}$ Perlindungan hukum berlaku juga dalam proses penuntutan dan proses pemeriksaan di sidang pengadilan. ${ }^{22}$ Jika diperlukan, perlindungan hukum dapat dilakukan secara khusus dan tanpa batas waktu. ${ }^{23}$ Tata cara pemberian perlindungan hukum dilaksanakan berdasarkan ketentuan Undang-Undang. ${ }^{24}$ Masalahnya, mekanisme yang ditunjuk oleh Undang-Undang Nomor 13 Tahun 2006 tentang Perlindungan Saksi dan Korban, tidaklah mudah dalam aplikasinya.

Dikaitkan dengan Undang-Undang Nomor 8 Tahun 1981 tentang Hukum Acara Pidana (HAP), yang kurang mengakomodir perlindungan saksi dan korban, sehingga sebagai ilmu hukum dogmatik tidak dapat menghadapi situasi yang baru, dengan meminjam istilah Satjipto Rahardjo maka diperlukan hukum yang progresif dimana hukum adalah untuk manusia. ${ }^{25}$ Berdasarkan Pasal 1 angka 3 Undang-Undang Nomor 13 Tahun $2006^{26}$ dan Pasal 1 angka 6 Peraturan Pemerintah Nomor 44 Tahun $2008^{27}$ dinyatakan bahwa LPSK adalah lembaga yang bertugas dan berwenang untuk memberikan perlindungan dan hak-hak lain kepada saksi dan atau korban sebagaimana diatur dalam Undang-Undang Nomor 13 tahun 2006 tentang Perlindungan Saksi dan Korban. Secara garis besarnya LPSK:

a. LPSK adalah lembaga mandiri, berkedudukan di Jakarta dan mempunyai perwakilan di daerah sesuai kebutuhan. ${ }^{28}$

b. LPSK bertanggungjawab pada Presiden dan wajib membuat laporan secara berkala kepada DPR sedikitnya sekali dalam setahun. ${ }^{29}$

c. Anggota LPSK terdiri atas 7 (tujuh) orang yang berasal dari unsur profesional yang mempunyai pengalaman di bidang pemajuan, pemenuhan, perlindungan, penegakan hukum dan hak asasi manusia, kepolisian, kejaksaan, Departemen Hukum dan Hak Asasi Manusia, akademisi, advokat, atau lembaga swadaya masyarakat. ${ }^{30}$

d. Masa jabatan anggota LPSK adalah 5 (lima) tahun dan setelah berakhir masa jabatan dapat dipilih kembali dalam jabatan yang sama, hanya untuk 1 (satu) kali masa jabatan berikutnya. ${ }^{31}$

\section{Sistem Penegakan Hukum Pidana terhadap Kekerasan dalam Rumah Tangga (KDRT)}

Masalah penegakan hukum dalam KDRT, dikaitkan dengan Teori Legal System dari Lawrence

\footnotetext{
Pasal 40 ayat (1) Rancangan Kitab Undang-Undang Hukum Acara Pidana.

Pasal 40 ayat (2) Rancangan Kitab Undang-Undang Hukum Acara Pidana.

Pasal 40 ayat (3) Rancangan Kitab Undang-Undang Hukum Acara Pidana.

Pasal 40 ayat (5) Rancangan Kitab Undang-Undang Hukum Acara Pidana.

Satjipto Rahardjo, 2006, Sisi-Sisi Lain dari Hukum Indonesia, Penerbit Buku Kompas, Jakarta, hlm. 16.

Pasal 1 angka 3 Undang-Undang Nomor 13 Tahun 2006 tentang Perlindungan Saksi dan Korban (Lembaran Negara Republik Indonesia Tahun 2006 Nomor 64, Tambahan Lembaran Negara Republik Indonesia Nomor 4635).

27 Pasal 1 angka 6 Peraturan Pemerintah Republik Indonesia Nomor 44 Tahun 2008 tentang Pemberian Kompensasi, Restitusi, dan Bantuan Kepada Saksi dan Korban (Lembaran Negara Republik Indonesia Tahun 2008 Nomor 84, Tambahan Lembaran Negara Republik Indonesia Nomor 4860)

28 Pasal 11 Undang-Undang Nomor 13 Tahun 2006 tentang Perlindungan Saksi dan Korban (Lembaran Negara Republik Indonesia Tahun 2006 Nomor 64, Tambahan Lembaran Negara Republik Indonesia Nomor 4635).

29 Pasal 13 Undang-Undang Nomor 13 Tahun 2006 tentang Perlindungan Saksi dan Korban (Lembaran Negara Republik Indonesia Tahun 2006 Nomor 64, Tambahan Lembaran Negara Republik Indonesia Nomor 4635).

30 Pasal 14 Undang-Undang Nomor 13 Tahun 2006 tentang Perlindungan Saksi dan Korban (Lembaran Negara Republik Indonesia Tahun 2006 Nomor 64, Tambahan Lembaran Negara Republik Indonesia Nomor 4635).

31 Pasal 15 Undang-Undang Nomor 13 Tahun 2006 tentang Perlindungan Saksi dan Korban (Lembaran Negara Republik Indonesia Tahun 2006 Nomor 64, Tambahan Lembaran Negara Republik Indonesia Nomor 4635).
} 
M. Friedman bahwa, "A legal system in actual operation is a complex organism in which structure, substance and culture interact". ${ }^{32}$

\section{a. Substansi Hukum}

Norma-norma hukum (peraturan, keputusan) yang dihasilkan dari produk hukum. Eksistensi Lembaga Perlindungan Saksi dan Korban (selanjutnya disingkat LPSK) berdasarkan Undang-Undang Nomor 13 Tahun 2006, dikorelasikan dengan kasus KDRT, maka ada sejumlah problematika, antara lain: Pertama, keberadaan saksi dan pelapor. Undang-Undang Nomor 13 Tahun 2006 tentang Perlindungan Saksi dan Korban menyebutkan, saksi adalah orang yang dapat memberikan keterangan guna kepentingan penyelidikan, penyidikan, penuntutan, dan pemeriksaan di sidang pengadilan tentang suatu perkara pidana yang ia dengar sendiri, ia lihat sendiri dan atau ia alami sendiri. ${ }^{33}$ Pasal 10 ayat (1) UU Perlindungan Saksi dan Korban memang menyebutkan adanya perlindungan bagi saksi, korban maupun pelapor dalam bentuk tidak dapat dituntut secara hukum baik pidana maupun perdata. Namun perlindungan bagi pelapor hanya sebatas itu saja. Tidak sebanyak dan selengkap perlindungan yang diberikan bagi seorang saksi seperti yang dicantumkan dalam Pasal 5 ayat (1) Undang-Undang Perlindungan Saksi dan Korban.

Dalam Pasal 5 ayat (1) UndangUndang Nomor 13 Tahun 2006, yang berbunyi: "Seorang Saksi dan Korban berhak: (a) Memperoleh perlindungan atas keamanan pribadi, keluarga dan harta bendanya, serta bebas dari ancaman yang berkenaan dengan kesaksiannya yang akan, sedang, atau telah diberikannya; (b) Ikut serta dalam proses memilih dan menentukan bentuk perlindungan dan dukungan keamanan; (c) Memberikan keterangan tanpa tekanan, (d) Mendapat penerjemah; (e) Bebas dari pertanyaan yang menjerat; (f) Mendapatkan informasi mengenai perkembangan kasus; (g) Mendapat informasi mengenai putusan pengadilan; (h) Mengetahui dalam hal terpidana dibebaskan; (i) Mendapat identitas baru; (j) Mendapat tempat kediaman baru; (k) Memperoleh penggantian biaya transportasi sesuai dengan kebutuhan; (l) Mendapat nasihat hukum; dan/atau (m) Memperoleh bantuan biaya hidup sementara sampai batas waktu perlindungan berakhir". Selanjutnya dalam Pasal 5 ayat (2) hak sebagaimana dimaksud pada ayat (1) diberikan kepada saksi dan/ atau korban tindak pidana dalam kasus-kasus tertentu sesuai dengan keputusan Lembaga Perlindungan Saksi dan Korban/LPSK

Kedua, pengklasifikasian Hak Korban. Menurut Andi Mattalatta pengertian korban yang mendasari lahirnya kajian viktimologi, pada awalnya hanya terbatas pada korban kejahatan. ${ }^{34}$ Namun selain dari korban kejahatan terdapat korban pengertian korban yang ada dalam masyarakat (korban bencana alam dan seterusnya). Korban dalam konteks ini merupakan korban dalam pengertian yang konvensional dan sekaligus sebagai cikal bakal yang menjadi objek kajian pada awal lahirnya viktimologi (klasik). Sedangkan menurut Arief Gosita, korban adalah mereka

32 Lawrence F. Friedman, 1975, The Legal System of Social Science Perspective, Russel Sage Foundation, New York, hlm. 5 bahwa proses bekerjanya hukum terdiri dari:

a. Struktur hukum: yaitu bagian yang bergerak dalam suatu mekanisme yang merupakan pelembagaan yang diciptakan oleh sistem hukum (mencakup wadah atau bentuk dari sistem hukum seperti lembaga-lembaga dan hubungan atau pembagian kekuasaan antar lembaga).

b. Substansi hukum: yaitu hasil aktual yang diterbitkan oleh sistem hukum baik peraturan, keputusan yang digunakan oleh penegak hukum maupun mereka yang diatur oleh hukum.

c. Budaya hukum: yaitu berupa ide-ide, sikap, harapan dan pendapat tentang hukum sebagai keseluruhan faktor yang menentukan bagaimana sistem hukum memperoleh tempatnya yang logis untuk menerima hukum atau sebaliknya.

Pasal 1 angka 1 Undang-Undang Nomor 13 Tahun 2006 tentang Perlindungan Saksi dan Korban (Lembaran Negara Republik Indonesia Tahun 2006 Nomor 64, Tambahan Lembaran Negara Republik Indonesia Nomor 4635).

34 J.E. Sahetapy (Ed.), 1987, Viktimologi: Sebuah Bunga Rampai, Pustaka Sinar Harapan, Jakarta, hlm. 43-44. 
yang menderita jasmaniah dan rohaniah sebagai akibat tindakan orang lain yang mencari pemenuhan diri sendiri atau orang lain yang bertentangan dengan kepentingan dan hak asasi yang menderita. ${ }^{35}$ Selanjutnya dalam Pasal 1 angka 2 Undang-Undang Nomor 13 Tahun 2006 tentang Perlindungan Saksi dan Korban dinyatakan bahwa korban adalah seseorang yang mengalami penderitaan fisik, mental, dan/atau kerugian ekonomi yang diakibatkan oleh suatu tindak pidana. ${ }^{36}$

Hukum pidana yang sekarang berlaku, mengasumsikan bahwa pihak korban telah memperoleh kepuasan keadilan dengan dipidananya pelaku kejahatan, karena pelaku kejahatan dalam hal ini telah merasakan juga penderitaan sebagaimana yang dialami/ diderita oleh korban. Asumsi ini barangkali hanya berada dalam lingkup kepuasan moril, akan tetapi jika dihubungkan dengan keadaan korban yang menderita luka fisik, terutama bagi korban yang tidak mampu secara finansial, maka dengan pemenuhan aspek kepuasan moril saja belum dapat dikatakan sebagai adanya suatu keseimbangan perlakuan antara pelaku dan korban. ${ }^{37}$

Pemidanaan saat ini tidak lagi berorientasi pada penjeraan/pembalasan, melainkan lebih berorientasi pada perbaikan atau pembinaan si pelaku, yaitu dengan berbagai sebutan antara lain seperti: rehabilitasi, reformasi, treatment of offenders, re-edukasi, readaptasi sosial, resosialisasi, pemasyarakatan dan lain-lain. ${ }^{38}$ Ada beberapa tujuan pemidanaan seperti dirumuskan dalam Konsep dalam Rancangan KUHP Pasal 47 disebutkan bahwa: Pertama, pemidanaan bertujuan untuk: (1) mencegah dilakukannya tindak pidana dengan menegakkan norma hukum demi pengayoman masyarakat; (2) memasyarakatkan terpidana dengan mengadakan pemidanaan sehingga menjadikannya orang yang baik dan berguna; (3) menyelesaikan konflik yang ditimbulkan oleh tindak pidana, memulihkan keseimbangan dan mendatangkan rasa damai dalam masyarakat; (4) membebaskan rasa bersalah pada terpidana. Kedua, pemidanaan tidak dimaksudkan untuk menderitakan dan tidak diperkenankan merendahkan martabat manusia.

Menurut Wirjono Prodjodikoro terkait perlu/tidaknya pelaku tindak pidana dijatuhi hukuman akan berhubungan dengan pandangan-pandangan yaitu: Pertama, teori negativisme dimana menurut HazewinkelSuringa bahwa si penjahat tidak boleh dilawan dan musuh tidak boleh dibenci. Kedua, teori absolut/mutlak dimana kejahatan harus diikuti dengan pidana, tidak boleh ditawar lagi. Menurut J.M. van Bemmelen dan W.F.C. van Hattum dalam bukunya Handen Leerboek van het Nedherlansche bahwa sudah selayaknya kejahatan ditanggapi dengan suatu pidana yang dilimpahkan kepada si penjahat, tidak perlu dicari alasan lagi. Ketiga, teori relatif/nisbi (Doel Theorien) dimana Kejahatan tidak mutlak harus diikuti dengan pidana, melainkan harus dipersoalkan juga perlu dan manfaatnya suatu pidana bagi masyarakat atau bagi si penjahat sendiri, tidaklah dilihat masa lampau tetapi juga masa depan. Keempat, teori gabungan

35 Arief Gosita, 1989, Masalah Perlindungan Anak, Akademika Presindo, Jakarta, hlm. 75. Pasal 1 angka 1 Undang-Undang Nomor 13 Tahun 2006 tentang Perlindungan Saksi dan Korban (Lembaran Negara Republik Indonesia Tahun 2006 Nomor 64, Tambahan Lembaran Negara Republik Indonesia Nomor 4635).

36 Pasal 1 angka 2 Undang-Undang Nomor 13 Tahun 2006 tentang Perlindungan Saksi dan Korban (Lembaran Negara Republik Indonesia Tahun 2006 Nomor 64, Tambahan Lembaran Negara Republik Indonesia Nomor 4635).

37 Iswanto, 1995, Restitusi Kepada Korban Mati atau Luka Berat sebagai Syarat Pidana Bersyarat pada Tindak Pidana Lalu Lintas, Disertasi, Program Doktor Ilmu Hukum Universitas Gadjah Mada, Yogyakarta, hlm. 2.

38 Barda Nawawi Arief, 1996, Bunga Rampai Kebijakan Hukum Pidana, Citra Aditya Bakti, Bandung, hlm. 86. 
(Verenigings - Theorien) dimana teori ini mengakui adanya unsur pembalasan (vergelding) dalam hukum pidana tetapi di lain pihak juga mengakui adanya unsur "preverensi" dan unsur "memperbaiki si penjahat". 39

Kedudukan korban yang terabaikan ini dan terkesan lebih memperhatikan pelaku, jelas merupakan suatu ketidakadilan. Kalaupun korban difungsikan dalam proses peradilan pidana, tidak lebih hanya sebagai pendukung penguasa (Jaksa/ Penuntut Umum) dalam rangka "penegakan ketertiban". Sementara itu "nasibnya" sendiri sebagai pihak yang dirugikan oleh suatu perbuatan pidana, terisolasi atau paling tidak, kurang mendapat perhatian, teracuhkan. Korban dalam hal ini menurut Arif Gosita "hanya difungsikan/dimanfaatkan sebagai sarana pembuktian saja". ${ }^{40}$

Problematika selanjutnya adalah substansi dalam Pasal 6 Undang-Undang Nomor 13 Tahun $2006^{41}$ membedakan dua jenis hak korban. Korban kejahatan "konvensional" tidak berhak atas bantuan medis dan bantuan rehabilitas psikososial dimana hak tersebut hanya diberikan kepada korban dalam pelanggaran hak asasi manusia yang berat. Di samping itu, korban dalam pelanggaran hak asasi manusia yang berat, melalui LPSK, berhak mengajukan kompensasi dan restitusi, sedangkan korban kejahatan "konvensional" hanya berhak mengajukan restitusi saja. Pasal 1 angka 7 Peraturan Pemerintah Republik Indonesia Nomor 44 Tahun $2008^{42}$ juga menyatakan bahwa layanan yang diberikan kepada korban dan atau saksi oleh LPSK dalam bentuk bantuan medis dan rehabilitasi psikososial, ${ }^{43}$ ternyata hanya untuk korban pelanggaran hak asasi berat. Dengan pengklasifikasian tersebut, secara tidak langsung akan berpengaruh terhadap penegakan hukum KDRT (yang masuk kejahatan konvensional).

Ketiga, belum terintegrasikannnya perlindungan saksi dan korban dalam KUHAP. Undang-Undang Nomor 13 Tahun 2006 tentang Perlindungan Saksi dan Korban bukanlah lex specialis dari KUHAP dan kenyataannya UU tersebut lahir untuk melengkapi KUHAP. Namun alangkah baiknya jika Perlindungan Saksi dan Korban diintegrasikan dalam KUHAP, meskipun dalam sub-bab tersendiri, mengingat perlindungan saksi dan korban adalah berkaitan dengan tersangka/terdakwa dikarenakan keduanya akan bersinggungan dalam mengungkapkan dugaan tindak pidana yang dilakukan tersangka. Di samping itu, tidak adanya reward bagi pelapor yang membongkar tindak pidana misalnya dalam bentuk bantuan hukum.

Keempat, belum terintegrasinya kelembagaan Lembaga Perlindungan Saksi dan Korban (LPSK) yang diatur dalam Undang-Undang Nomor 13 Tahun 2006 sebagai Criminal Justice System. LPSK yang berpusat di Jakarta dengan perwakilan di daerah sesuai dengan "keperluan". Indikator keperluan itu yang bagaimana, sedangkan jika terjadi tindak pidana diperlukan perlindungan saksi dan korban. Bagaimana jika di daerah belum/tidak dibentuk? Akankah penegakan hukum menjadi dikesampingkan?

\footnotetext{
Wirjono Prodjodikoro, 1989, Asas-Asas Hukum Pidana di Indonesia, Eresco, Bandung, hlm. 20-25. Iswanto, Op.cit, hlm. 68.

Pasal 6 Undang-Undang Nomor 13 Tahun 2006 tentang Perlindungan Saksi dan Korban (Lembaran Negara Republik Indonesia Tahun 2006 Nomor 64, Tambahan Lembaran Negara Republik Indonesia Nomor 4635).

42 Pasal 34 ayat (1) Undang-Undang Nomor 13 Tahun 2006 tentang Perlindungan Saksi dan Korban (Lembaran Negara Republik Indonesia Tahun 2006 Nomor 64, Tambahan Lembaran Negara Republik Indonesia Nomor 4635).

43 Pasal 1 angka 7 Peraturan Pemerintah Republik Indonesia Nomor 44 Tahun 2008 tentang Pemberian Kompensasi, Restitusi, dan Bantuan Kepada Saksi dan Korban (Lembaran Negara Republik Indonesia Tahun 2008 Nomor 84, Tambahan Lembaran Negara Republik Indonesia Nomor 4860).
} 
Bagaimana pula tugas Polisi dan Kejaksaan (sebagai integrated criminal system)? Misalnya, dalam Pasal 30 ayat (1) huruf e Undang-Undang Nomor 16 Tahun 2004 tentang Kejaksaan disebutkan bahwa untuk melengkapi berkas perkara tertentu dan untuk itu dapat melakukan pemeriksaan tambahan sebelum dilimpahkan ke pengadilan yang dalam pelaksanaannya dikoordinasikan dengan penyidik. ${ }^{44}$

Kelima, pembatasan saksi dan korban yang dilindungi. Undang-Undang Nomor 13 Tahun 2006 sebagaimana disebutkan dalam Pasal 5 ayat (2) dan penjelasannya bahwa perlindungan terhadap saksi dan korban untuk tindak pidana dalam kasus tertentu yaitu antara lain tindak pidana korupsi, tindak pidana narkotika/psikotropika, tindak pidana terorisme dan "tindak pidana lain yang mengakibatkan posisi saksi dan korban di hadapkan situasi yang membahayakan jiwanya dan ini diputuskan oleh LPSK". Artinya, perlindungan saksi dan korban untuk kasus KDRT oleh LPSK, masih dapat dimungkinkan, jika membahayakan jiwanya.

Keenam, terkesan kontraproduktif antara Undang-Undang Nomor 23 Tahun 2004 tentang Penghapusan Kekerasan dalam Rumah Tangga dengan Undang-Undang Nomor 13 Tahun 2006 tentang Perlindungan Saksi dan Korban, dalam hal penting atau tidaknya memberikan Perlindungan pada saksi dan korban. Dalam Pasal 224 KUHP berbunyi, "Barangsiapa dipanggil sebagai saksi, ahli atau juru bahasa menurut undangundang dengan sengaja tidak memenuhi kewajiban berdasarkan Undang-Undang yang harus dipenuhinya, dalam perkara pidana, diancam dengan pidana penjara paling lama sembilan bulan $[\ldots]$ ". ${ }^{45}$ Akibatnya saksi hanya dibebani kewajiban dan tidak mempunyai hak.

Dengan lahirnya kedua UU tersebut, saksi termasuk korban mempunyai hak. Namun hak-hak korban yang diatur dalam Pasal 10 Undang-Undang Nomor 23 Tahun 2004 tentang Penghapusan Kekerasan dalam Rumah Tangga Undang-Undang tidak serta merta akan mendapatkan perlindungan dari LPSK sebab perlindungan terhadap saksi dan korban antara lain dengan pertimbangan sifat pentingnya saksi dan korban, tingkat ancaman yang membahayakan keselamatannya, hasil analitis tim medis atau psikolog terhadap saksi dan atau korban, disamping prosedur tata cara perlindungan yang memerlukan mekanisme yang tidak mudah termasuk persetujuan oleh pengadilan atas pengajuan LPSK.

\section{b. Struktur Hukum}

Kelembagaan yang diciptakan sistem hukum yang memungkinkan pelayanan dan penegakan hukum. Sistem Peradilan Pidana atau Criminal Justice System sebagaimana dikemukakan oleh Pakar Hukum Pidana dan para ahli Sistem Peradilan Pidana dari USA. Frank Hagan membedakan antara Criminal Justice System dengan Criminal Justice Process, dimana "Criminal Justice System is the system bye which society, first determines what will constitute a crime and then identifies, accuses, tries, convicts and punishes those who violated the criminal law", sedangkan Criminal Justice Process adalah "[...] the series off procedure bye which society identifies, accuses, tries, convicts and punishes offenders". ${ }^{46}$ Ini berbeda dengan pendapatnya Hulsman

44 Pasal 30 ayat (1) huruf e Undang-Undang Nomor 16 Tahun 2004 tentang Kejaksaan (Lembaran Negara Republik Indonesia Tahun 2004 Nomor 67, Tambahan Lembaran Negara Republik Indonesia Nomor 4401).

45 Moeljatno, 1996, Terjemahan Kitab Undang-Undang Hukum Pidana (KUHP), Bina Aksara, Jakarta.

46 Romli Atmasasmita, 1982, Strategi Pembinaan Pelanggar Hukum dalam Konteks Penegakan Hukum di Indonesia, Penerbit Alumni, Bandung, hlm. 70 . 
dalam Muladi ${ }^{47}$ diungkapkan bahwa Sistem Peradilan Pidana pada hakikatnya merupakan masalah social dengan alasan: "(1) The Criminal Justice System inflict suffering; (2) The Criminal Justice System doesn't work in term of its own declared aims; (3) Fundamental uncontrollability of criminal justice system; (4) Criminal Justice System approach is fundamentally flawed niches offenders". Dalam pandangan demikian, dapat difahami bahwa dalam Sistem Peradilan Pidana dituntut adanya keselarasan hubungan antara sub-sistem dalam peradilan pidana (khususnya dalam persoalan administrasi peradilan) kaitannya dengan Law Enforcement sehingga akan membawa keberhasilan dalam penerapan prinsipprinsip hukum dan asas-asas hukum (pidana) yang menjadi dasar kerangka normatif sistem peradilan pidana yang terpadu. Sedangkan dari pengertian Sistem Peradilan Pidana tersebut di atas dapat diketahui bahwa Criminal Justice System fokusnya lebih kepada substantive law, sedangkan Criminal Justice Process fokusnya lebih pengamanan penerapan substantive law. Menurut Romli Atmasasmita, Criminal Justice Process dimulai dari penangkapan, penggeledahan, penahanan, penuntutan dan pemeriksaan di muka sidang pengadilan serta diakhiri dengan pelaksanaan pidana di Lembaga Pemasyarakatan, ${ }^{48}$ yang dapat difahami sebagai mekanisme peradilan pidana sebagai suatu proses berdasarkan peraturan yang berlaku terutama KUHAP.

Menurut Mardjono Reksodipoetro, "Sistem Peradilan Pidana adalah sistem pengendalian kejahatan yang terdiri dari lembaga-lembaga Kepolisian, Kejaksaan, Pengadilan dan Pemasyarakatan terpidana". ${ }^{49}$
Oleh sebab itu, kurang bijaksana kalau pemahaman terhadap sistem hanya sebatas sub sistem, artinya tugas pemberian perlindungan saksi dan korban utamanya menjadi tugas Kepolisian, dengan mengesampingkan peran institusi penegak hukum lainnya seperti Penuntut Umum, Pengadilan. Akibatnya sudah dapat diduga bahwa Sistem Peradilan Pidana yang sedemikian kompleksnya tidak dapat berfungsi sebagaimana mestinya tanpa dukungan semua pihak termasuk masyarakat.

Kepolisian sebagai ujung tombak dalam penegakan hukum yang mempunyai tugas pokok memelihara keamanan dan ketertiban memiliki kewajiban memberikan perlindungan serta rasa keadilan kepada masyarakat. Dibentuknya Ruang Pelayanan Khusus (berasal dari anggota Polwan yang telah dibekali pelatihan dalam masalah keluarga), yang dibantu dari pihak rumah sakit, atau lembaga swadaya masyarakat yang memiliki perhatian khusus dalam masalah keluarga ${ }^{50}$ diharapkan dapat membantu penegakan hukum dalam mengungkap kasuskasus KDRT.

Selama ini KDRT diidentifikasikan dengan delik aduan. Padahal Pasal 351 KUHP (tentang penganiayaan) dan Pasal 356 (tentang Pemberatan), ternyata tidak diisyaratkan adanya aduan. Hanya saja khususnya penegak hukum, jika suatu kejahatan yang berhubungan dengan keluarga, maka dilihat sebagai delik aduan padahal itu adalah kasus criminal murni. Seharusnya, jika kemudian korban menarik aduannya, maka hendaknya penegak hukum dapat meneruskannya ke pengadilan sebab dasar hukumnya yakni UU PKDRT sebagaimana diatur dalam Pasal 103 KUHP bahwa "jika Undang-Undang menentukan lain", maka ketentuan dalam 
Bab I sampai VIII tidak berlaku. Berdasarkan penelitian yang dilakukan oleh Malkani, ${ }^{51}$ dapat disimpulkan:

a. Persoalan KDRT tidak mudah untuk menyelesaikan, sebab dalam setiap penyelesaian kasus KDRT hampir diperhadapkan pada dua kepentingan yang saling berbenturan, yakni satu sisi menyangkut kepentingan yuridis dan sisi lain menyangkut kepentingan kemanusiaan, sehingga dalam praktik penyelesaiannya tidak jarang dilakukan dengan cara damai berdasarkan kewenangan diskresioner kepolisian.

b. Kendala yang ditemui dalam pelaksanaan pola dan prosedur penyidikan KDRT yaitu korban yang mau melaporkan dan perkaranya memenuhi syarat formil maupun materiil, tidak jarang mencabut kembali karena merasa sangat memerlukan masa depan anak-anaknya dan masih menginginkan rumah tangganya dapat dibangun kembali.

c. Tampaknya budaya patriarki masih mendominasi dalam kehidupan rumah tangga, kaum laki-laki atau pihak suami merasa superior sehingga kalaupun dia berada pada posisi telah melakukan kesalahan, tapi tetap tidak menerima kesalahannya dengan lapang dada, bahkan mengancam akan bercerai karena isteri telah melaporkan kasus KDRT tersebut ke Rumah Perempuan dan Polisi. Begitupun juga suami yang telah dijatuhi sanksi pidana oleh putusan pengadilan karena terbukti bersalah, pada akhirnya tetap bersikeras hati dan tidak mau lagi melanjutkan perkawinan mereka atau dia tidak mau pulang ke rumah tangganya.

Persoalan diskresi oleh Kepolisian, tidak dapat dilepaskan dengan UndangUndang Nomor 2 Tahun 2002 tentang Kepolisian dimana Pasal 16 ayat (2) menyatakan bahwa syarat diskresi tidak bertentangan dengan aturan hukum, selaras dengan kewajiban hukum yang mengharuskan tindakan tersebut dilakukan, harus patut, masuk akal dan termasuk dalam lingkungan jabatannya, pertimbangan yang banyak berdasarkan keadaan yang memaksa dan menghormati hak asasi manusia. ${ }^{52}$ Ketentuan di atas sebagai kontrol diperbolehkannya diskresi sebab dalam Pasal 16 ayat (1) Undang-Undang Nomor 2 Tahun 2002 tentang Kepolisian "hanya" menyebutkan bahwa Kepolisian diberikan wewenang untuk mengadakan tindakan lain menurut hukum yang bertanggungjawab (termasuk diskresi), ${ }^{53}$ mengingat tidak ada batasan/rumusan tindakan diskresi.

Penelitian yang dilakukan oleh Lamber Missa menyimpulkan, ternyata semua laporan kasus KDRT ke pihak Kepolisian tidak serta merta dilimpahkan ke Kejaksaan sehingga diteruskan proses hukumnya di pengadilan, kemungkinan besar filterisasi yang terlaporkan atau mungkin kepolisian menggunakan "power of discretion". ${ }^{44}$ Aparat penegak hukum termasuk LPSK harus proaktif dalam menangani kasus KDRT. Kalau kasus KDRT sampai di

51 Malkani, 2012, Dilematis Pemeriksaan Tersangka oleh Penyidik terhadap Tindak Pidana Kekerasan dalam Rumah Tangga di Polres Bukittinggi, Hasil Laporan, Pasca Sarjana Universitas Andalas dengan Universitas Muhammadiyah, Padang. Romli Atmasasmita, 1983, Bunga Rampai Hukum Acara Pidana, Bina Cipta, Bandung, hlm. 17.

52 Pasal 16 ayat (2) Undang-Undang Nomor 2 Tahun 2002 tentang Kepolisian (Lembaran Negara Republik Indonesia Tahun 2002 Nomor 2, Tambahan Lembaran Negara Republik Indonesia Nomor 4168).

53 Pasal 16 ayat (1) Undang-Undang Nomor 2 Tahun 2002 tentang Kepolisian (Lembaran Negara Republik Indonesia Tahun 2002 Nomor 2, Tambahan Lembaran Negara Republik Indonesia Nomor 4168).

54 Lamber Missa, 2010, Studi Kriminologi Penyelesaian Kekerasan dalam Rumah Tangga di Wilayah Kota Kupang Propinsi Nusa Tenggara Timur, Tesis, Program Magister Ilmu Hukum Universitas Diponegoro, Semarang. 
persidangan, hakim dituntut untuk melakukan rechtvinding (penemuan hukum) dengan segala kewenangan yang ada padanya seperti telah diamanatkan dalam Undang-Undang Nomor 14 Tahun 1970 tentang KetentuanKetentuan Pokok Kekuasaan Kehakiman jo. Undang-Undang Nomor 48 Tahun 2009 tentang Kekuasaan Kehakiman, ${ }^{55}$ dimana hakim wajib untuk menggali nilai-nilai yang hidup dan berkembang di masyarakat.

\section{c. Budaya Hukum}

Ide-ide, sikap, harapan, pendapat, dan nilai-nilai yang berhubungan dengan hukum (bisa positip/negatif). Hasil penelitian I Ketut Widiarta sebagaimana disampaikan oleh Heri Utomo, Kanit Reskrim pada Polres Kapuas:

Tidak semua perkara pidana dapat dilakukan melalui dimensi mediasi penal. Di Polres Kapuas, kasus KDRT yang memiliki preferensi untuk dapat diselesaikan melalui mediasi penal adalah tindak pidana KDRT yang dilakukan tersangka (pelaku) digolongkan ringan. Dengan kata lain, tidak menimbulkan korban jiwa, luka berat dan akibat dari perbuatan pelaku dapat diperbaiki/dipulihkan. Terkecuali tindak pidana KDRT tersebut menimbulkan dampak yang berat bagi korban baik secara psikis maupun fisik atau bahkan sampai meninggal dunia, maka terhadap kasus seperti demikian akan diteruskan proses hukumnya. ${ }^{56}$

Penyelesaian sengketa di luar pengadilan (ADR atau "Alternative Dispute Resolution", umumnya digunakan dalam kasus-kasus perdata dan berdasarkan perundang-undangan yang berlaku di Indonesia, pada prinsipnya kasus pidana tidak dapat diselesaikan di luar pengadilan, walaupun dalam hal-hal tertentu, dimungkinkan adanya penyelesaian kasus pidana di luar pengadilan. Faktor korban KDRT tidak melaporkan penderitaaan yang menimpanya: Pertama, si pelaku dan korban memiliki hubungan kekeluargaan atau hubungan perkawinan; Kedua, keengganan korban melapor karena didasari pola pikir bahwa kekerasan dalam rumah tangga adalah masalah keluarga sehingga melaporkan berarti membuka aib keluarga; Ketiga, kekurangpercayaaan masyarakat pada sistem hukum di Indonesia sehingga mereka tidak memiliki pegangan dan kepastian jika akan keluar dari cengkraman pelaku. ${ }^{57}$

Hal tersebut berkaitan dengan budaya hukum suatu masyarakat. Menurut Daniel S. Lev di dalam karangannya Judicial Institutions, and Legal Culture in Indonesia sebagaimana dikutip oleh Esmi Warassih Pujirahayu, ${ }^{58}$ sistem hukum yang menekankan pada prosedur tetapi tidak menjelaskan tentang bagaimana sesungguhnya orangorang itu menyelesaikan masalahnya seharihari, sehingga nilai hukum prosedural hanya mempersoalkan tentang cara pengaturan masyarakat, sedangkan nilai hukum substantif dari budaya hukum terdiri dari asumsi fundamental mengenai distribusi maupun penggunaan sumber-sumber di masyarakat terutama mengenai apa yang adil dan tidak menurut masyarakat.

\section{Penutup}

Persoalan muncul dalam penegakan hukum terhadap kasus kekerasan dalam rumah tangga (KDRT) mulai dari struktur (aparat penegak hukum termasuk LPSK), substansi UU dan budaya

55 Pasal 5 ayat (1) Undang-Undang Nomor 48 Tahun 2009 tentang Kekuasaan Kehakiman (Lembaran Negara Republik Indonesia Tahun 2009 Nomor 157, Tambahan Lembaran Negara Republik Indonesia Nomor 5076).

56 I Ketut Widiarta, 2012, Penyelesaian Perkara KDRT Melalui Mediasi Penal pada Tingkat Penyidikan di Polres Kapuas, Hasil Penelitian, Program Magister Ilmu Hukum Universitas Brawijaya, Malang.

57 Dikdik M.Arif dan Elisatris Gultom, Op.cit., hlm. 135.

58 Esmi Warasssih Pujirahayu, 2005, Pranata Hukum-Sebuah Telaah Sosiologis, Suryandaru Utama, Semarang, hlm. 104. 
hukum masyarakat yang cenderung menyelesaikan secara kekeluargaan. Eksistensi Undang-Undang Nomor 13 Tahun 2006 tentang Perlindungan Saksi dan Korban dan Peraturan Pemerintah Republik Indonesia Nomor 44 Tahun 2008 tentang Pemberian Kompensasi, Restitusi, dan Bantuan kepada Saksi dan Korban, dalam tataran praktis terdapat beberapa kelemahan, seperti belum terakomodirnya pelapor, mekanisme untuk memperoleh perlindungan/ prosedur dan peruntukan perlindungan hanya untuk tindak pidana tertentu termasuk kompensasi dan restitusi. Politik hukum di masa mendatang, berupa regulasi peraturan harus lebih mengakomodir kebutuhan hukum masyarakat khususnya saksi dan korban (termasuk pelapor) termasuk dalam kasuskasus KDRT, termasuk peraturan pelaksanaannya di samping masukan dari berbagai pihak yang konstruktif untuk menemukan kebenaran materiel.

\section{DAFTAR PUSTAKA}

\section{A. Buku}

Arief, Barda Nawawi, 1996, Bunga Rampai Kebijakan Hukum Pidana, Citra Aditya Bakti, Bandung.

Atmasasmita, Romli, 1982, Strategi Pembinaan Pelanggar Hukum dalam Konteks Penegakan Hukum di Indonesia, Penerbit Alumni, Bandung. , 1983, Bunga Rampai Hukum Acara Pidana, Bina Cipta, Bandung.

Friedman, Lawrence F., 1975, The Legal System of Social Science Perspective, Russel Sage Foundation, New York.

Gosita, Arief, 1989, Masalah Perlindungan Anak, Akademika Presindo, Jakarta.

Luhulima, Achie Sudiarti, 2000, Pemahaman Bentuk-Bentuk Tindak Kekerasan terhadap Perempuan dan Alternatif Pemecahannya, Alumni, Bandung.

Mansur, Dikdik M. Arief dan Elisatris Gultom, 2008, Urgensi Perlindungan Korban Kejahatan, Raja Grafindo Persada, Jakarta.

Moeljatno, 1996, Terjemahan Kitab UndangUndang Hukum Pidana (KUHP), Bina Aksara, Jakarta.

Muladi, 1995, Kapita Sistem Peradilan Pidana, BP Undip, Semarang.

Parsons, Talcott and Robert F. Bales (Ed.), 1955, Family, Socialization and Interaction Process, The Free Press, Glencoe.
Prodjodikoro, Wirjono, 1989, Asas-Asas Hukum Pidana di Indonesia, Eresco, Bandung.

Pujirahayu, Esmi Warasssih, 2005, Pranata HukumSebuah Telaah Sosiologis, Suryandaru Utama, Semarang.

Reksodipoetro, Mardjono, 1993, Sistem Peradilan Pidana Indonesia, FH UI, Jakarta.

Sahetapy, J.E. (Ed.), 1987, Victimologi Sebuah Bunga Rampai, Pustaka Sinar Harapan, Jakarta.

Sudarto, 1981, Hukum dan Hukum Pidana, Alumni, Bandung.

\section{B. Tugas Akhir/Hasil Penelitian}

Iswanto, 1995, Restitusi kepada Korban Mati atau Luka Berat sebagai Syarat Pidana Bersyarat pada Tindak Pidana Lalu Lintas, Disertasi, Program Doktor Ilmu Hukum Universitas Gadjah Mada, Yogyakarta.

Malkani, 2012, Dilematis Pemeriksaan Tersangka oleh Penyidik terhadap Tindak Pidana Kekerasan dalam Rumah Tangga di Polres Bukittinggi, Hasil Penelitian, Program Kerjasama Pasca Sarjana Universitas Andalas dengan Universitas Muhammadiyah, Padang.

Missa, Lamber, 2010, Studi Kriminologi Penyelesaian Kekerasan dalam Rumah Tangga di Wilayah Kota Kupang Propinsi Nusa Tenggara Timur, Tesis, Program Magister Ilmu Hukum Universitas Diponegoro, Semarang. 
Widiarta, I Ketut, 2012, Penyelesaian Perkara KDRT melalui Mediasi Penal pada Tingkat Penyidikan di Polres Kapuas, Hasil Penelitian, Program Magister Ilmu Hukum Universitas Brawijaya, Malang.

\section{Peraturan Perundang-Undangan/Konsep KUHP dan KUHAP}

Undang-Undang Nomor 8 Tahun 1981 tentang Hukum Acara Pidana (Lembaran Negara Republik Indonesia Tahun 1982 Nomor 76, Tambahan Lembaran Negara Republik Indonesia Nomor 3209).

Undang-Undang Nomor 2 Tahun 2002 tentang Kepolisian (Lembaran Negara Republik Indonesia Tahun 2002 Nomor 2, Tambahan Lembaran Negara Republik Indonesia Nomor 4168).

Undang-Undang Nomor 16 Tahun 2004 tentang Kejaksaan (Lembaran Negara Republik Indonesia Tahun 2004 Nomor 67, Tambahan Lembaran Negara Republik Indonesia Nomor 4401).

Undang-Undang Nomor 23 Tahun 2004 tentang Penghapusan Kekerasan dalam Rumah Tangga (Lembaran Negara Republik Indonesia Tahun 2004 Nomor 95, Tambahan
Lembaran Negara Republik Indonesia Tahun 2004 Nomor 4419).

Undang-Undang Nomor 13 Tahun 2006 tentang Perlindungan Saksi dan Korban (Lembaran Negara Republik Indonesia Tahun 2006 Nomor 64, Tambahan Lembaran Negara Republik Indonesia Nomor 4635).

Undang-Undang Nomor 26 Tahun 2000 tentang Pengadilan Hak Asasi Manusia (Lembaran Negara Republik Indonesia Tahun 2000 Nomor 208, Tambahan Lembaran Negara Republik Indonesia Nomor 4026).

Undang-Undang Nomor 48 Tahun 2009 tentang Kekuasaan Kehakiman (Lembaran Negara Republik Indonesia Tahun 2009 Nomor 157, Tambahan Lembaran Negara Republik Indonesia Nomor 5076).

Peraturan Pemerintah Republik Indonesia Nomor 44 Tahun 2008 tentang Pemberian Kompensasi, Restitusi, dan Bantuan kepada Saksi dan Korban (Lembaran Negara Republik Indonesia Tahun 2008 Nomor 84, Tambahan Lembaran Negara Republik Indonesia Nomor 4860).

Rancangan Kitab Undang-Undang Hukum Acara Pidana. 